\title{
VIII. Description of an improved air-pump
}

\section{T. Sylvester Esq.}

To cite this article: T. Sylvester Esq. (1806) VIII. Description of an improved air-pump, Philosophical Magazine Series 1, 26:101, 38-40, DOI: 10.1080/14786440608563629

To link to this article: http://dx.doi.org/10.1080/14786440608563629

曲 Published online: 18 May 2009.

Submit your article to this journal

Џ Article views: 3

Q View related articles $₫$ 
and which has much resemblance to that of burnt onions. M. Antoine, huwever, compares it to the udour of caramel. The alkalis form with it soluble salts, and that of soda, among others, of a fresh savour, slightly bitter, and which leaves in the mouth a taste like that of green nuts.

Barytes, strontian, or lime, united to this acid give very insoluble salts, susceptible of solution in an excess of acid, but difficultly: all of them present themselves under the form of tlakes more or less light. It possesses the remarkable property of decomposing, in general, all the earhy acetates without having recourse to double affinities : it also decomposes severd metallic solutions, and in a remarkable manner those of iron, which it precipitates white though at the maximum; those of copper it precipitates of a blueish green. The acetate of lead is aiso precipitated in white flakes, which are insoluble in vinegar.

If in place of employing this free acid we take one of its alkaline combinations, precipitates are obtained, in the solutions, of aluminous and magnesian salts; but it is necessary that the latter be very much concentratcd, without which the precipitates are redissolved immediately.

[To be continued.]

VIII. Description of an improved Air-Pump. By T. Sylvester, Esq.

$\mathrm{O}_{\mathrm{NE} \text { of }}^{\sin }$ To Mr. Tilloch. air-pump arises from the difficulty in opening the valves at the bottom of the barrels, which imperfection was thought to have been remedied by the introduction of stop-cocks; but experience shows that, however accurate they may be when new, after a little use they became faulty.

I here send you a description of an air-pump, which $\mathbf{I}$ Jately executed, without either valves or stop-cock. I have supplied their place by a slide, which is shifted at every motion of the piston, in a similar manner to that of a stopcock, which requires no pressure of the air to open it. It moves between two facings of leather, which lessens fric- 
tion and procures a close fitting of the parts; and if after use it should at any time be found not air-tight, the defect is instantly remedied by means of four screws; which is a considerable advantage over stop-cocks. The manner of its application is shown in fig. 1. (Plate II.); the perspective is considerably strained for the purpose of rendering the construction more intelligible. $\mathrm{AB}$ is the barrel, having a strong plate of brass, CDEF, firmly fixed to the bottom with two small holes, $\mathrm{G}$ and $\mathrm{H}$, that enter the inside; but near the edge of the barrel IKLM is another plate of brass similar to the former, having two holes, $\mathrm{N}$ and $\mathrm{O}$, that correspond with $\mathbf{G}$ and $\mathrm{H}$. In the hole $\mathrm{N}$ is closely screwed the duct $\mathrm{P}$, which leads to the receiver of the pump; and in the bole $O$ is screwed the duct $Q$, through which the air is discharged. The plates, being ground smooth, are faced with leather, picrced opposite the holes, and smeared with grease; then the polished brass slide $R S$, fig. 2 , is placed between them. In the slide is a hole $\mathrm{T}$, which is put over the hole $\mathbf{N}$. The plates are then pressed together by the four screws $V, U, W, X$, which screw into nuts that are fixed into the bottom part of the machine; they also serve to direct the motion of the slide, which is drawn backwards and forwards. When the hole $\mathrm{T}$ is between $\mathrm{N}$ and $\mathrm{G}$, the piston $\mathrm{Y}$ is drawn up, which causes the air to rush out of the receiver through the duct $P$ into the barrel; the slide is then drawn by the ring $Z$, for the bole $T$ to be between $O$ and $H$. The communication between the barrel and discharging duct $Q$ is opened; the piston is then forced down, and the air is discharged. The slide is again shifted; which closes up the discharging aperture and opens the former, and the process is continued until the receiver is exhausted. At each end of the slide is a small ridge of brass that prevents its being pushed or pulled too far, so that the hole in the slide will exactly correspond with the holes in the plates.

If the pump has two barrels, by making the slide a little longer, and with two boles, it will serve both by only once moving; and, from what has been said, it is evident that, merely by changing the motion of the slide, the machine will condense as well as exhaust. When the receiver is ex- 
Mr Silvester's Air Pump.

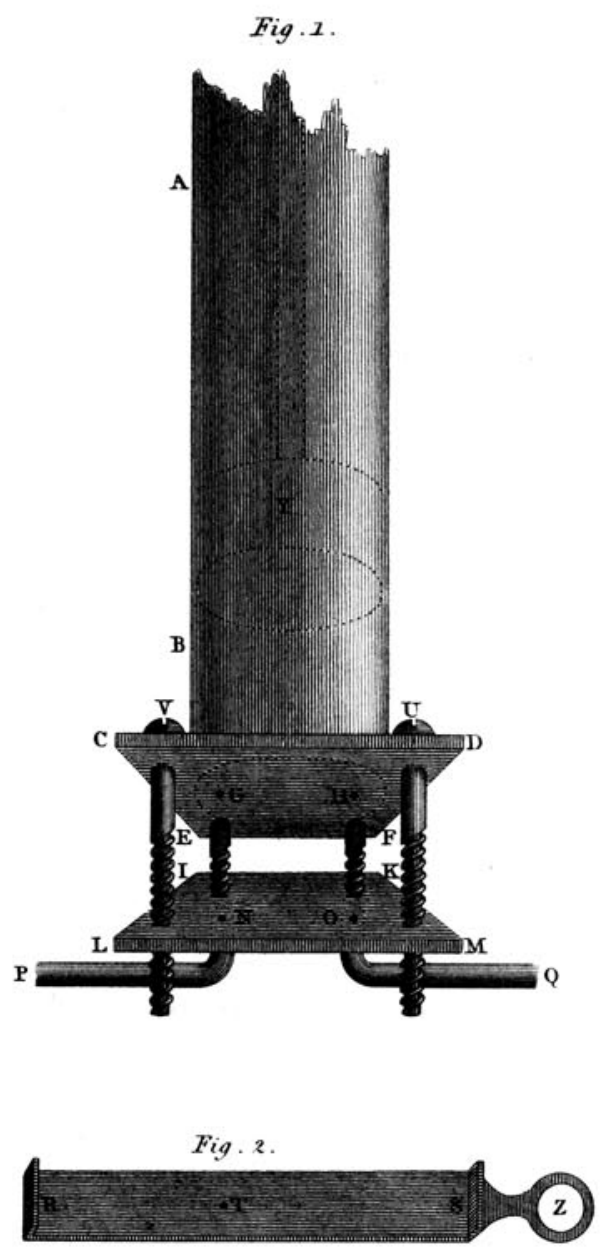


hausted, the air is readmitted by a stop-cock under the plate of the receiver.

If you think the above improvement worth inserting in your Philosophical Magazine, by so doing you will greatly oblige

Worcester, Sept. 12, 1806.

Your very humble servant,

T. Sylvester.

IX. A Memoir on the lest Method of measuring Time at Sea, which ollained the double Prize adjudged by the Royal Academy of Sciences; containing the Description of the Longitude Watch presented to His Majesty* the 5th of August 1766. By M. LE Roy, Clock-maker to the Kingt. Translated from the French l'y Mr.T. S. Evans, F.L.S., of the Royal Miiitury Academy, Woolwich.

A great deal has lately been said on the subject of chronometers, more especially with regard to what is contained in the description given by M. le Roy of his time-keeper; and the work to which, that description is subjoined being now in the hands of very few persons, the translator thought this paper in English might be a valuable addition to the very little useful matter which we possess on that branch of mechanics. It has been asserted that the greater part of the improvements in chronometers, lately laid before the Board of Longitude, are mentioned in this account of Le Roy's; the public will therefore now have it in their power to judge for themselves.

T.S. E.

$$
\begin{aligned}
& \text { Labor omnia vincit } \\
& \text { Improbus. }
\end{aligned}
$$

InTRODUCTION.

$\mathrm{BY}$ proposing to determine the best method of measuring time at sea, the Academy appears to require, first, such a measure of time as may give to mariners the knowledge of the longitude which has been so much desired, that for many

* Louis XV. king of France.

+ This Memoir is subjoincd to the Voyage fait par ortre du Roi en 1768, pour éprozter les montres marines investées par M. Le Roy, par M. Citssini, fils. Paris 1770. 4to. 